\title{
A new species of the bee genus Paratetrapedia from northeastern Brazil mimic of the stingless bee Camargoia nordestina (Apidae, Tapinotaspidini)
}

\author{
Antonio J. C. Aguiar ${ }^{1,2 *}$ (), Matheus Cavalcante Viana ${ }^{2}$, Gabriel A. R. Melo ${ }^{3}$ (]) \\ ${ }^{1}$ Universidade de Brasília, Instituto de Ciências Biológicas, Departamento de Zoologia, Brasília, DF, Brasil. \\ ${ }^{2}$ Universidade de Brasília, Programa de pós-graduação em Zoologia, Brasília, DF, Brasil. \\ ${ }^{3}$ Universidade Federal do Paraná, Departamento de Zoologia, Curitiba, PR, Brasil. \\ urn:Isid:zoobank.org:pub:70C2C8A3-978B-430E-880D-488DDA188EDD
}

\section{A R T I C L E I N F O}

\section{Article history:}

Received 09 October 2020

Accepted 17 January 2021

Available online 22 March 2021

Associate Editor: Eduardo Almeida

\section{Keywords:}

Endemism

Mimicry

Oil-bees

Semideciduous forests

Taxonomy

\begin{abstract}
A B S T R A C T
The northeastern region in Brazil comprises a complex of endemic areas mostly known for the species inhabiting the dry Caatinga and wet Atlantic forests. Here, we describe the new bee species Paratetrapedia nordestina sp. nov. (Tapinotaspidini), which occurs in enclaves of semi-deciduous forests in the western limits of Ceará and in eastern Piaui state, in northeastern Brazil. A key to both males and females of the lineata group in Paratetrapedia, including the new species, is provided. We also provide a discussion about its mimetic partner, map of distribution, and main illustrations of the two involved species.
\end{abstract}

\section{Introduction}

The description of biodiversity is a continuous work of taxonomists and it is mostly supported by a gradual improvement of collections through significant actions like field expeditions, curation of collections, review of type specimens, single isolated descriptions and production of monographic revisions (Winston, 1999; Wiley and Lieberman, 2011). The order Hymenoptera represents one of the richest or perhaps the richest insect order with more than 153,000 species described, and between 400,000 to more than $1,000,000$ species estimated (Aguiar et al., 2013; Forbes et al., 2018). The bees, representing one of the largest families of Hymenoptera, is a very successful group of animals, with more than 18,000 described species worldwide (Michener, 2007; Aguiar et al., 2013), over 5,000 of them found in the Neotropics, and about 1,700 in Brazil (Moure et al., 2007). Despite the extensive study of numerous specimens in monographic revisions, the discovery of new species is not uncommon especially when poorly known areas are sampled and when there are species complex with inconspicuous variation that

\footnotetext{
${ }^{*}$ Corresponding author.

E-mail: ajcaguiar@gmail.com (A.J.C. Aguiar).
}

requires a closer scrutiny of the specimens (e.g. Faria and Melo, 2012; Griswold and Gonzalez, 2015; Melo, 2015).

Most of the northeastern region in Brazil is occupied by the Caatinga domain, a set of xeric-adapted plant formations; whereas the Atlantic Forests is mostly distributed on the eastern coast of northeastern Brazil, the Cerrado on plateaus, and Amazonian-related forests on the western and northwestern portions of this region (IBGE, 2004). However, there are several smaller endemic areas that make the northeastern region of Brazil a complex mosaic, with very heterogeneous enclaves of humid and dry tropical forests, wetlands, transitional vegetation types, grasslands, and rupestrian grasslands (Queiroz et al., 2017).

Most of the knowledge about the biodiversity of northeastern Brazil is concentrated on the east and northern portions, while the central and western portions are poorly known (Lessa et al., 2019). There is an urgent need to collect and describe the biodiversity of central and southern portions of this region due a strong pressure for coal, pasture and soybean monoculture, mostly on grasslands areas and semi-deciduous forests of the states of Maranhão, Tocantins, Piauí, and Bahia, jointly referred to as "MATOPIBA", a very large area that is 
prone to an almost complete extirpation of the natural areas in the next decades (Matricardi et al., 2018).

Here we describe a new species of a solitary bee of the genus Paratetrapedia, with a discussion of its mimetic partner. In addition to the description, we present a key for the lineata species group, to which the new species belongs, as well as illustrations and maps of distribution for both involved species.

\section{Material and methods}

Material of the following collections was studied: Entomological Collection Pe. Jesus Santiago Moure da Universidade Federal do Paraná, Curitiba, Brazil (DZUP) and Coleção de Insetos do Centro de Coleções Taxonômicas da Universidade Federal de Minas Gerais, Belo Horizonte, Brazil (UFMG). The terminology used in the descriptions of morphology follows Michener (1944), Urban (1967), and Michener (2007), except for the use of metapostnotum (Brothers, 1976) instead of propodeal triangle. The flagellomeres of the antenna are indicated as F1, F2, etc.; terga and sterna, respectively, as T1 to T7 and S1 to S8. The deeply impressed area above the antennal fovea is referred to as the antennal scrobe. The tergal and sternal bands of hairs mentioned in the descriptions are located at the posterior margins of these sclerites. The carina on the vertex, posterior to the ocelli, is here designated as the post-ocellar carina instead of pre-occipital carina because of its uncertain homology with the limits of the occipital area (Silveira, 1995). The labels of the specimens examined were transcribed in the section Type material in the following way: one inverted bar ( $\$ ) to indicate different lines on the label, two inverted bars (II) to indicate that the inscription is on the back of the label, and quotation marks to indicate different labels on the same specimen. All measurements are in millimeters. The density of the punctures is relative to their diameters and the abbreviation pd is used for puncture diameter (e.g. $<2$ pd: distance between the punctures less than two times the diameter of the punctures). The size of the punctures was classified into four types: minute, fine, coarse, and very coarse following Aguiar and Melo (2007). The observations and descriptions were performed using a Leica M125 stereomicroscope equipped with a micrometer eye piece. The color images were obtained by a Leica DFC295 digital camera attached to the stereomicroscope Leica M125 and merged with the software Zerene Stacker (Version 1.04 Build) at Laboratório de Biologia Comparada de Hymenoptera of Universidade Federal do Paraná.

To estimate the potential distribution of the new species and its mimetic partner, we produced distribution maps based on climatic models. The climatic models used were obtained on Worldclim (https://www.worldclim.org), using a resolution of $2.5 \operatorname{arc}-\min \left(0.041^{\circ} \approx 4 \mathrm{~km}\right)$, and an additional test of correlation was performed to exclude the layers with high reciprocal correlation $(\leq 0.70$ ) as suggested by Segurado et al. (2006), and using the script on R system developed by Dalapicolla (2015). The climatic variables used were: Annual Mean Temperature(BIO1), Mean Diurnal Range(BIO2), Isothermality (BIO3), Annual Precipitation (BIO12) and Precipitation Seasonality (BIO15). For each species 15 models were performed and the selected algorithm to run the models was MaxEnt (Phillips et al., 2006). The values of AUC (Area Under Curve) of the models were used to estimate the fitness of the models (Fielding and Bell, 1997). The values of AUC varied between 0.5 to 1.0 ; when close to 1.0 indicates the best previsions of species occurrence between the 15 models. The model with highest value of AUC among the 15 runs was selected and treated on Qgis 3.4.4.

\section{Results}

Paratetrapedia nordestina sp. nov. Aguiar and Melo

urn:Isid:zoobank.org:act:3BFAFF51-14CB-4F4E-BA62-AB78D1412FAD (Figs. 1 and 2)
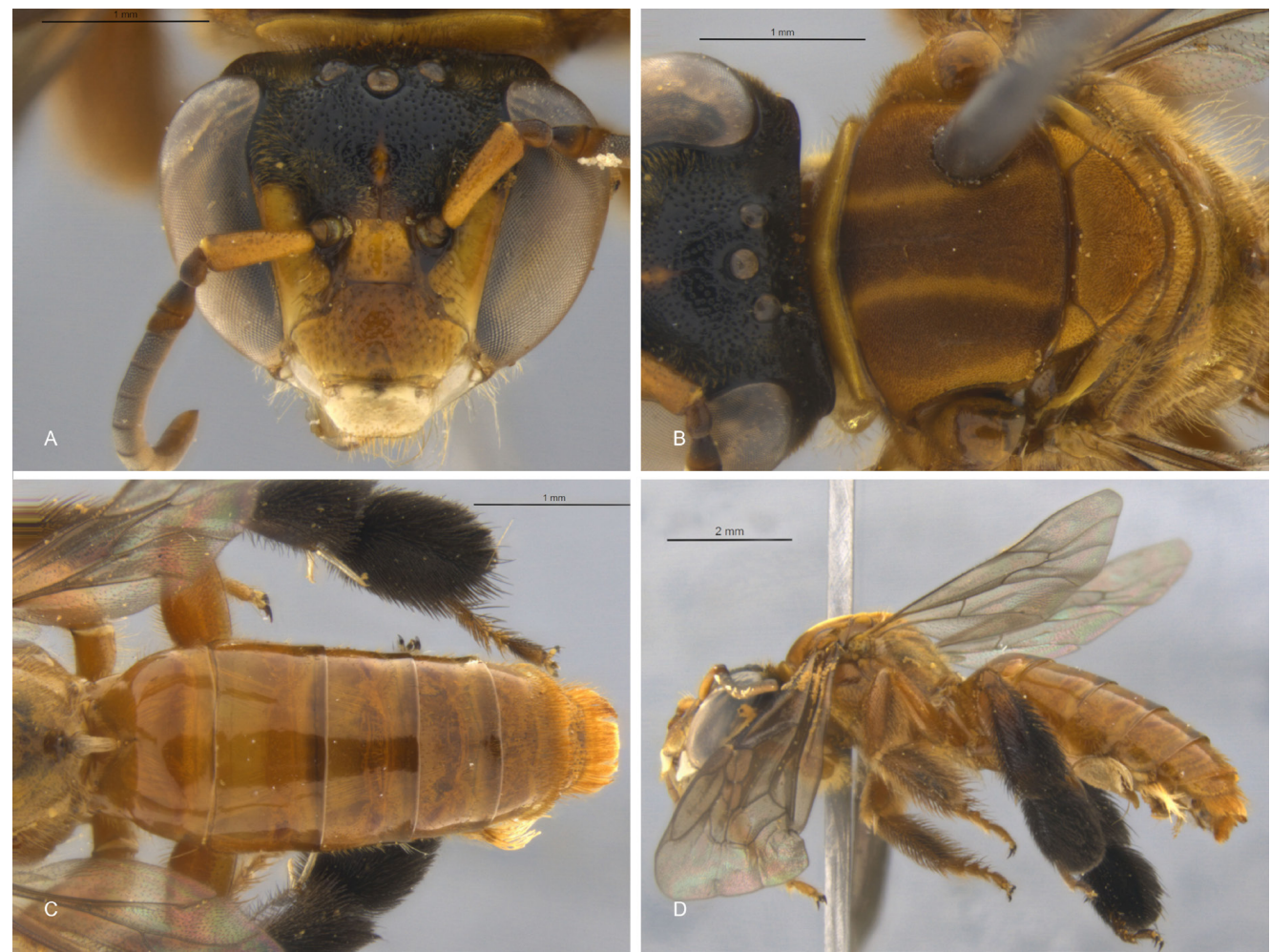

Figure 1 Holotype of Paratetrapedia nordestina sp. nov. 

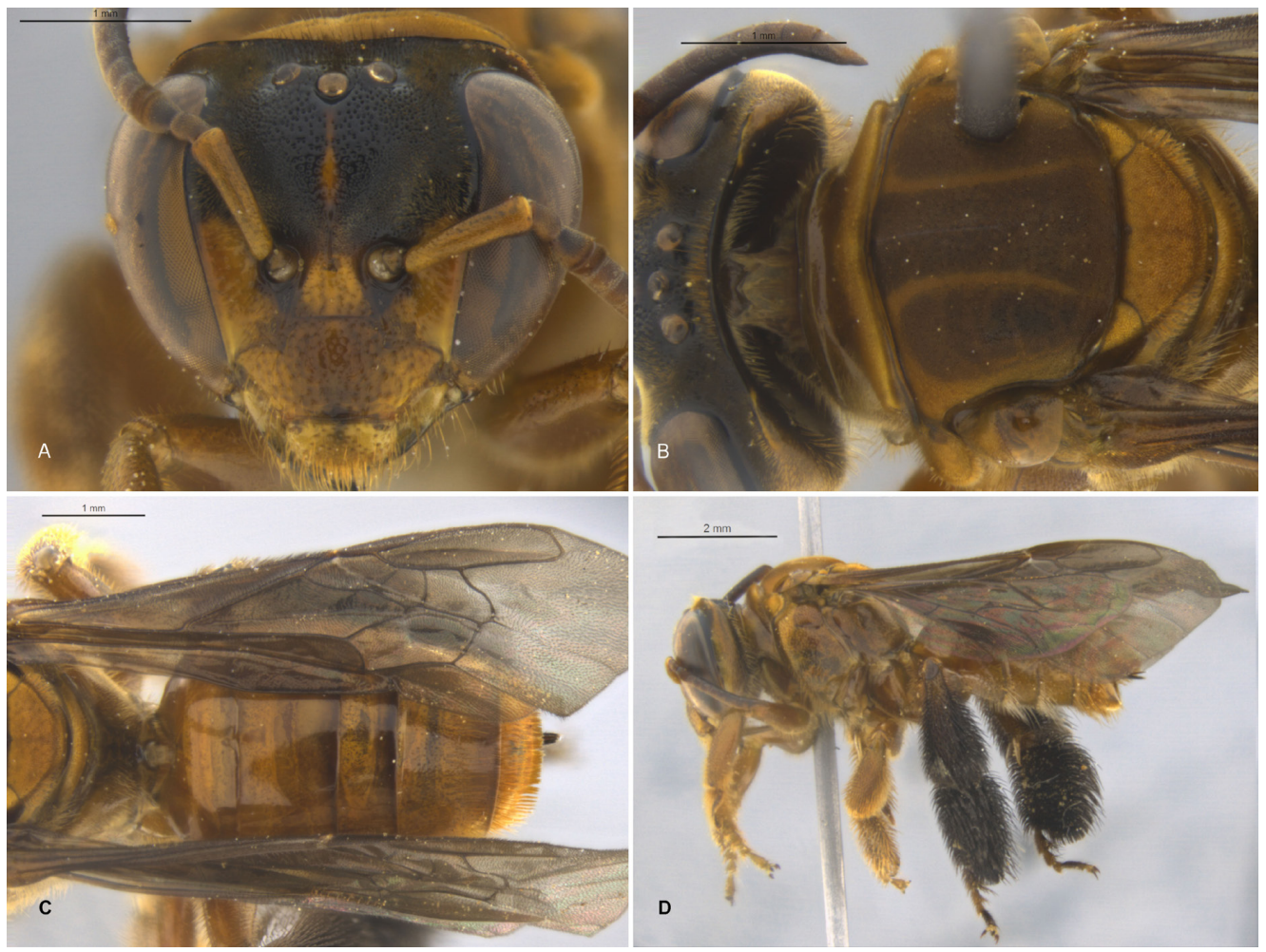

Figure 2 Paratype female of Paratetrapedia nordestina sp. nov.

\section{Diagnosis}

Paratetrapedia nordestina sp. nov. belongs in the lineata species group and exhibits all diagnostic characters of this group (see below and Aguiar and Melo, 2011: 387). It differs from the remaining species of the group by the wing membrane blackish infumate, the integument mostly reddish orange, mesoscutum reddish orange with thin paleyellow stripes on disc; frons, vertex and upper paraocular area brownish black; pubescence on hind tibia and basitarsus mostly black; terga mostly reddish brown with a thin pale orange margin.

\section{Comments}

Paratetrapedia nordestina sp. nov. is a member of the lineata species group in Paratetrapedia. This species group has now six species and it is easily recognized by the convex supraclypeal area, the fine long hairs on lower margin of mandibles of males, pronotal collar of females with an obtuse lamella, S2 of males with a small tuft of long hairs on mid portion and hind basitarsus of males with a small acute spine on anterior margin, among other characters that support the monophyly of the group in the phylogenetic study of the genus (Aguiar and Melo, 2011).

The specimens of Paratetrapedia nordestina sp. nov. collected in the RPPN Serra das Almas, at the border between Ceará and Piauí, were flying together with workers of the stingless bee Camargoia nordestina Camargo foraging on the same plants. Camargoia nordestina (Fig. 3) has the same size and color pattern of $P$. nordestina sp. nov. Their color patterns agree in many in details, like the blackish wings, the blackish frons and legs, and the reddish orange metasoma with pale orange stripes on margins, suggesting that these species pertain to a mimetic complex.

\section{Etymology}

The species name refers to the region where this species occurs and also to its mimetic partner Camargoia nordestina.

\section{Description}

Holotype male. Body length: 9.5; wing length: 7.0; maximum head width: 2.65 ; intertegular distance: 1.85 . Color. Integument mostly reddish to yellowish orange, except for: mandibles, gena and labrum pale white; clypeus and supraclypeal area yellowish orange; scape pale orange; pedicel and F1-F11 reddish brown; frons disc with a very narrow reddish yellow line; frons and vertex blackish; hind tibia and basitarsus dark reddish brown, almost black; paraocular area with a wide pale yellow mark occupying almost two-thirds of its length. Pronotum, mesepisternum, scutellum, metanotum, propodeum and metapostnotum yellowish orange; mesoscutum disc reddish, with narrow yellowish orange stripes on disc and lateral margins, bordering most of the lateral thirds. Metasoma mostly yellowish orange with faint brown stripes on tergal margins. Wing veins black, membrane darkly infumate and with dense cover of black microtrichiae. Pubescence. Pubescence pale yellow to blackish. Lower margin of mandibles, gena, ventral mesepisternum, fore and mid trochanter, and proximal portion of fore tibia with very long and thin setae, ca. $1.5 \mathrm{x}$ mandible maximum width. Labrum, clypeus, lower paraocular area and frons with inconspicuous pubescence, with scattered short simple erect setae; upper paraocular area, antennal scrobe, vertex and upper gena with dense short plumose pubescence. On mesoscutum and scutellum composed only by dense velvet plumose pale orange pubescence; posterolateral portions of scutellum with two to three long simple erect setae, and a very small inconspicuous tuft of plumose setae; axilla of scutellum with numerous long pale yellow simple setae; metapostnotum with numerous short plumose pale yellow setae; T1-T4 with a very short marginal band of plumose hairs on posterior lateral margins; T5 and T6 with a complete marginal band of dense plumose hairs on margin; T7 with apex completely covered by dense plumose pubescence. S2 with a small, isolated tuft of long simple setae on mid portion, and longer fringes on lateral thirds; S3 with a deep concave area covered by short plumose hairs; $\mathrm{S} 4$ with a dense fringe of long plumose hairs composing convergent bands on lateral portions; S5 and S6 with only a 

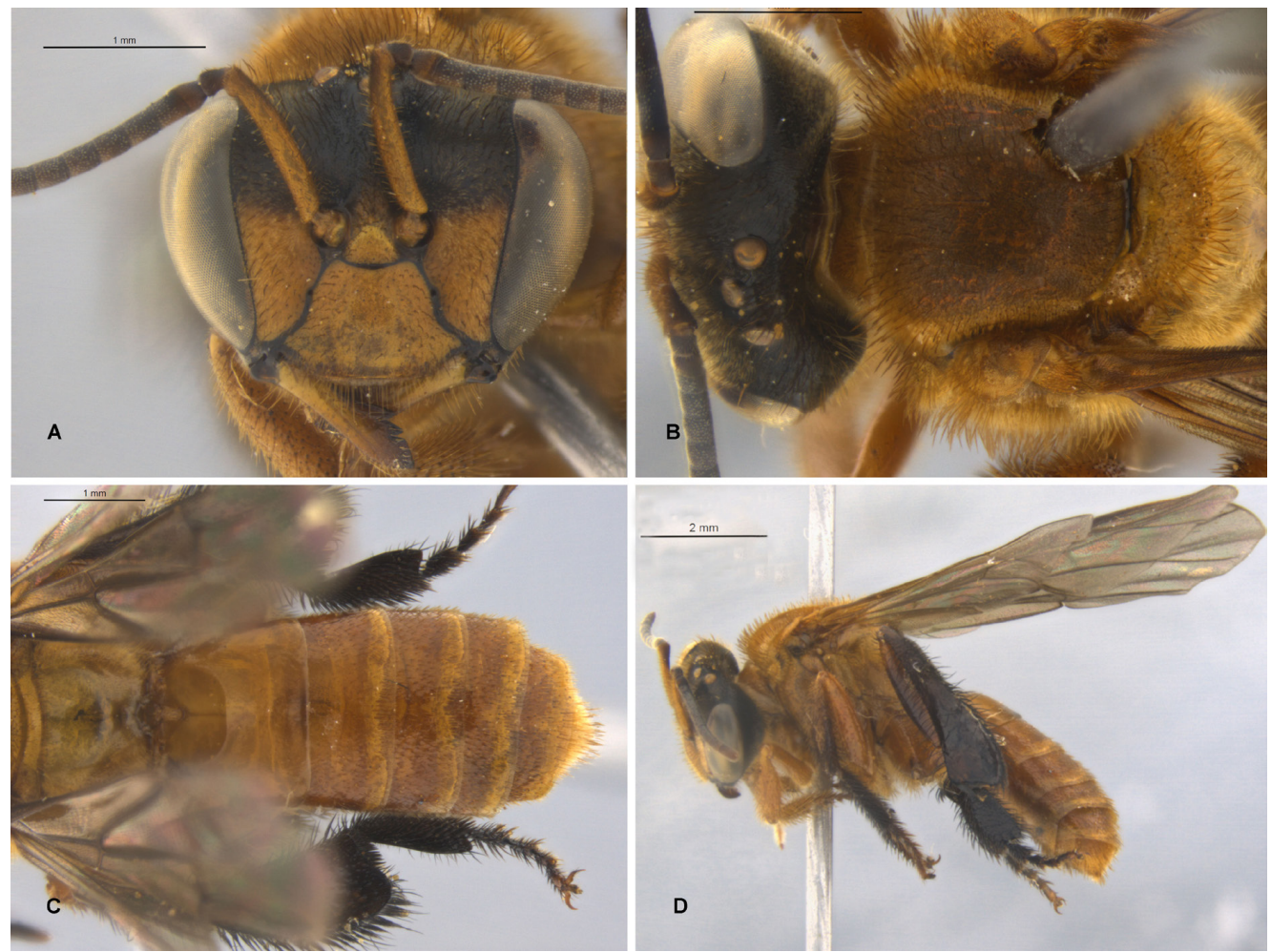

Figure 3 Camargoia nordestina, worker from Crateús, collected in the same flowers of P. nordestina.

small tuft of plumose hairs on posterolateral borders; hind tibia and hind basitarsus with dense plumose blackish hairs. Sculpture. Clypeus and supraclypeal area with dense and deeply concave coarse punctures, ca. $<0.5-1 \mathrm{pd}$; supraclypeal area strongly convex; frons with dense coarse punctures, ca. 2-5 pd; mesoscutum with dense fine minute punctures, almost contiguous; mesepisternum with numerous coarse punctures, ca. $0.5-1 \mathrm{pd}$; metapostnotum with numerous fine punctures, ca. $1 \mathrm{pd}$. Structure and measurements. Head approximately $1.2 x$ wider than long (2.65:2.1); compound eyes ca. $2.5 x$ longer than wide (1.8:0.6), inner orbits strongly convergent below (upper distance 1.5 , lower distance 1.15 ); clypeus $1.8 \mathrm{x}$ wider than long (1.0: 0.6$)$; lower third of frontal line thinly carinated; frons strongly convex, and antennal scrobe and upper paraocular area concave; scape length: 0.7, maximum width, 0.24 ; length of the first three flagellomeres $0.2,0.15,0.22$, respectively; gena in lateral view $0.5 \mathrm{x}$ as wide as eye width $(0.3 ; 0.6)$; scutellum disc slightly convex, mostly flat; hind wing with 11 hamuli; mid tibial spur finely serrate, $0.5 \mathrm{x}$ as long as basitarsus; $\mathrm{T} 2$ maximum width ca. $0.5 \mathrm{x}$ metasoma length. Hind basitarsus with a small acute spine on inner surface of proximal third.

\section{Female (paratype DZUP 027626)}

Body length: 8.0; wing length: 7.5; maximum head width: 2.75; intertegular distance: 1.9. Color. Similar to male, labrum, mandibles and gena slightly pale orange; T1 disc pale orange, lower third of vertical surface and distal third reddish orange; T2-T6 disc pale yellow, and marginal area reddish orange. Pubescence. Similar to male, except for clypeus with very short simple hairs, inconspicuous (ca. $0.4 \mathrm{x}$ F2 diameter); lower third of gena with long straight simple setae, ca. 2x F2 diameter; mesoscutum with velvet pubescence intermingled by sparse very short erect simple setae; posterolateral portion of scutellum with only one long simple erect setae; posterolateral margins of scutellum with short tufts of plumose hairs, shorter than F2 diameter; metapostnotum with very short pubescence, very inconspicuous; T5 with marginal band of short appressed simple hairs complete throughout the margin. Sculpture. Similar to male, clypeus and supraclypeal area with dense coarse punctures, almost contiguous; antennal scrobe and lateral portions of frons with fine minute punctures (ca. $0.2 \mathrm{pd}$ ); frons disc with dense coarse punctures (ca. $0.3 \mathrm{pd}$ ); mesoscutum and scutellum with dense fine minute punctures, almost contiguous, intermingled by very sparse minute punctures; metapostnotum with fine minute punctures ca. 1-2 pd, lateral margins mostly smooth; mesepisternum with numerous coarse punctures, ca. $1 \mathrm{pd}$. Structure and measurements. Head approximately $1.2 x$ wider than long (2.8:2.25); compound eyes ca. $2.5 x$ longer than wide (1.87:0.52), inner orbits strongly convergent below (upper distance 1.5 , lower distance 1.3 ); clypeus $1.8 \mathrm{x}$ wider than long (1.25: 0.55); lower third of frontal line thinly sulcate; frons strongly convex, and antennal scrobe and upper paraocular area concave; scape length: 1.25 , maximum width, 0.2 ; length of the first three flagellomeres $0.25,0.10,0.15$, respectively; gena in lateral view $0.5 \mathrm{x}$ as wide as eye width $(0.4 ; 0.7)$; scutellum disc slightly bilobate, mostly flat; hind wing with 9 hamuli; mid tibial spur finely serrate, $0.5 \mathrm{x}$ as long as basitarsus; T2 maximum width ca. $0.8 \mathrm{x}$ metasoma length $(4.35 ; 4.0)$.

\section{Type material}

Holotype male (DZUP), “DZUP\027627” “Brasil, Ceará, Crateús,| Serra das Almas $\backslash 05.1417^{\circ}$ S 40.9162ํW, $626 \mathrm{~m}, 23 . v .2014, \mid$ G. Melo \& B. Rosa"; paratypes: 2 females (DUZP), same data of holotype except "DZUP $\backslash$ 027628" and “DZUP $\mid$ 027626"; 1 male (UFMG), "Cristiano Castro PI\S das Confusões\ Brasil 01.04.2007\ C. Schlindwein leg." “33949 UFPE” “L189\Malpighiaceae”.

\section{Distribution}

The species is only recorded for the states of Ceará and Piauí, in the semi-deciduous forests. 


\section{Conservation status and threats}

Despite being known from only two locality records, which places the new species in a condition as data deficient (DD), it is associated with the semideciduous forests of northeastern Brazil. These forest formations currently suffer high rates of conversion to coal, pasture and other agricultural areas, making us to believe that the new species is highly threatened on sites outside the conservation areas.

Key to the lineata species group in Paratetrapedia (for both males and females; modified from Aguiar and Melo, 2011)

1. Integument mostly dark brown or black. . .2

- Integument mostly yellow to reddish orange. $\ldots 3$

2. Clypeus dark brown with yellow stripe usually occupying entire lower margin; supraclypeal area dark brown or black, in some specimens with small yellow spot on disc; scape completely reddish brown, in some specimens with one yellow spot on lower portion; tarsomeres dark brown or weakly reddish brown; wing membrane pale brown infumate; metapostnotum with dense fine punctures ( $1 \mathrm{pd})$; lamella of pronotal collar acute (Brazil: Espírito Santo, Minas Gerais, Paraíba, Paraná, Pernambuco, Rio de Janeiro, Santa Catarina, São Paulo; Paraguai)........................................................................ fervida (Smith)

- Clypeus and supraclypeal area completely yellow; scape mostly yellow; tarsomeres yellow; wing membrane dark brown infumate; metapostnotum with sparse fine punctures (2 pd); lamella of pronotal collar weakly obtuse on lateral portions (Mexico).................................................... mexicana Aguiar and Melo

3. Wing membrane blackish infumate; integument bicolor, mostly reddish orange, metasoma mostly reddish orange, with very faint and narrow blackish-brown stripes on tergal margins (semi-deciduous forests of northeastern Brazil)

Paratetrapedia nordestina sp. nov.

- Wing membrane mostly hyaline or pale white, in some species only the distal margin blackish; integument bicolor, pale orange and reddish brown, metasoma pale orange with conspicuous reddish brown to black stripes on disc of terga ...

. .4

4. Wing membrane yellow infumate; mesoscutum black with thin yellow stripes on disc, and usually very wide orange yellow stripes on lateral margins, occupying most of lateral portions, similar to P. duckei; terga completely orange yellow (Brazil: central Amazonas) ....................................... . alsinai Aguiar and Melo

- Wing membrane mostly hyaline, weakly milky white; mesoscutum mostly black, with thin yellow stripes on disc and lateral margins; terga with marginal zone completely dark brown..

5. Metanotum yellow laterally. Metapostnotum with fine punctures, surface between punctures smooth and shiny. Mesepisternum yellow laterally; metapostnotum and propodeum completely yellow; hind basitarsus with one long acute tooth on anterior margin; epistomal suture straight above upper margin of clypeus (Brazil: Goiás, Maranhão, Piauí, Tocantins)

P. tocantinensis Aguiar and Melo

- Metanotum reddish brown laterally. Metapostnotum with dense fine punctures, surface between punctures dull, with microsculpture of dense fine sulci; mesepisternum laterally mostly reddish brown, usually with one yellow spot on omaulus; metapostnotum reddish brown with one yellow spot on disc; propodeum completely reddish brown, some specimens with large yellow spots on anterior margin; hind basitarsus with one short acute tooth on anterior margin; epistomal suture strongly curved above upper margin of clypeus (Bolivia; Brazil: Acre, Mato Grosso, Pará, Rondônia; Peru) ..P. lineata(Spinola)

\section{Discussion}

The genus Paratetrapedia is mostly associated with wet forests, due to the behavior of making nests within rotten wood, which restrain the distribution of its species. Paratetrapedia nordestina sp. nov. was found in enclaves of seasonal semideciduous forests within the Caatinga domain, in areas at the top of the plateaus bordering the basin of the river Parnaíba. The northernmost record is within the Ibiapaba Plateau, which occupies the border between Ceará and Piauí states, with altitudes varying from 600 to $950 \mathrm{~m}$ a.s.l. and higher precipitation rates compared to neighboring areas. These areas function as islands of humidity placed within the semiarid landscape of the Caatinga domain (Uvo and Berndtsson, 1996).

We document here a mimicry relation between Paratetrapedia nordestina sp. nov. and the stingless bee Camargoia nordestina. Most species of Paratetrapedia, Tropidopedia, Lophopedia, and Nasutopedia exhibit color patterns that resemble those found in common co-occurring species of stingless bees (Aguiar and Melo, 2007; Aguiar, 2009; Aguiar and Melo, 2011; Aguiar, 2018). For example, many of the yellow species from the Amazon basin resemble the very abundant stingless bee species of the genera Ptilotrigona and Tetragona, while the black species resemble Trigona. The hypothesized mimicry of three species of Paratetrapedia in relation to stingless bees was previously observed among visitors of Byrsonima crassifolia, in which case stingless bee abundance surpass at least ten times that of Paratetrapedia species (Albuquerque and Rêgo, 1989; Rêgo and Albuquerque, 1989). Considering the much higher abundance of the stingless bee workers, we believe that they serve as models, and not the other way around. Although stingless bees lack a stinger, they are likely unpalatable due to secretions from some of their many exocrine glands (Melo, 2020).

From this standpoint, the relation between $P$. nordestina sp. nov. and $C$. nordestina is best characterized as Müllerian mimicry, since both species exhibit protections against their predators. But due to high asymmetry in abundance, the system probably behaves as in Batesian mimicry. One of the predictions of Batesian mimicry is that protection should break down where the dangerous model is absent, benefits of mimicry depending on abundance of the model (Bates, 1862). Camargoia nordestina is mostly related to the same seasonal semideciduous forests in the dry valleys of Serra de Ibiapaba (Camargo, 1996), however its distribution extends to Goiás, along the valley of Paranã river, Tocantins and to Bahia (Fig. 4). Paratetrapedia nordestina sp. nov. has only two geographical records, and its mimetic partner C. nordestina is known from at least ten localities. Despite the very similar color and body shape, suggesting a strong mimetic partnership, the comprehension of evolution of this complex is difficult because it can involve other species, and the distribution and abundance of these species are poorly known. Relative frequencies of models and mimics in both space and time play a profound role in how a mimicry relationship evolves and persists.

Three possible routes may govern the survival of the mimetic Paratetrapedia nordestina sp. nov. in the case of decrease of the abundance of the model Camargoia nordestina: the mimic P. nordestina sp. nov. may persist but at low abundance, especially when predation is weak, or it could go extinct locally due to intense predation increased by its conspicuousness, or alternative defensive strategies such as crypsis or disruptive coloration could evolve in the mimetic species (Pfennig et al., 2007; Prudic and Oliver, 2008; Prudic et al., 2019). We suggest the second option, assuming that the distribution of $P$. nordestina sp. nov. is dependent on the high abundance of $C$. nordestina, and it is absent on the borders of the distribution of the model, been only distributed 


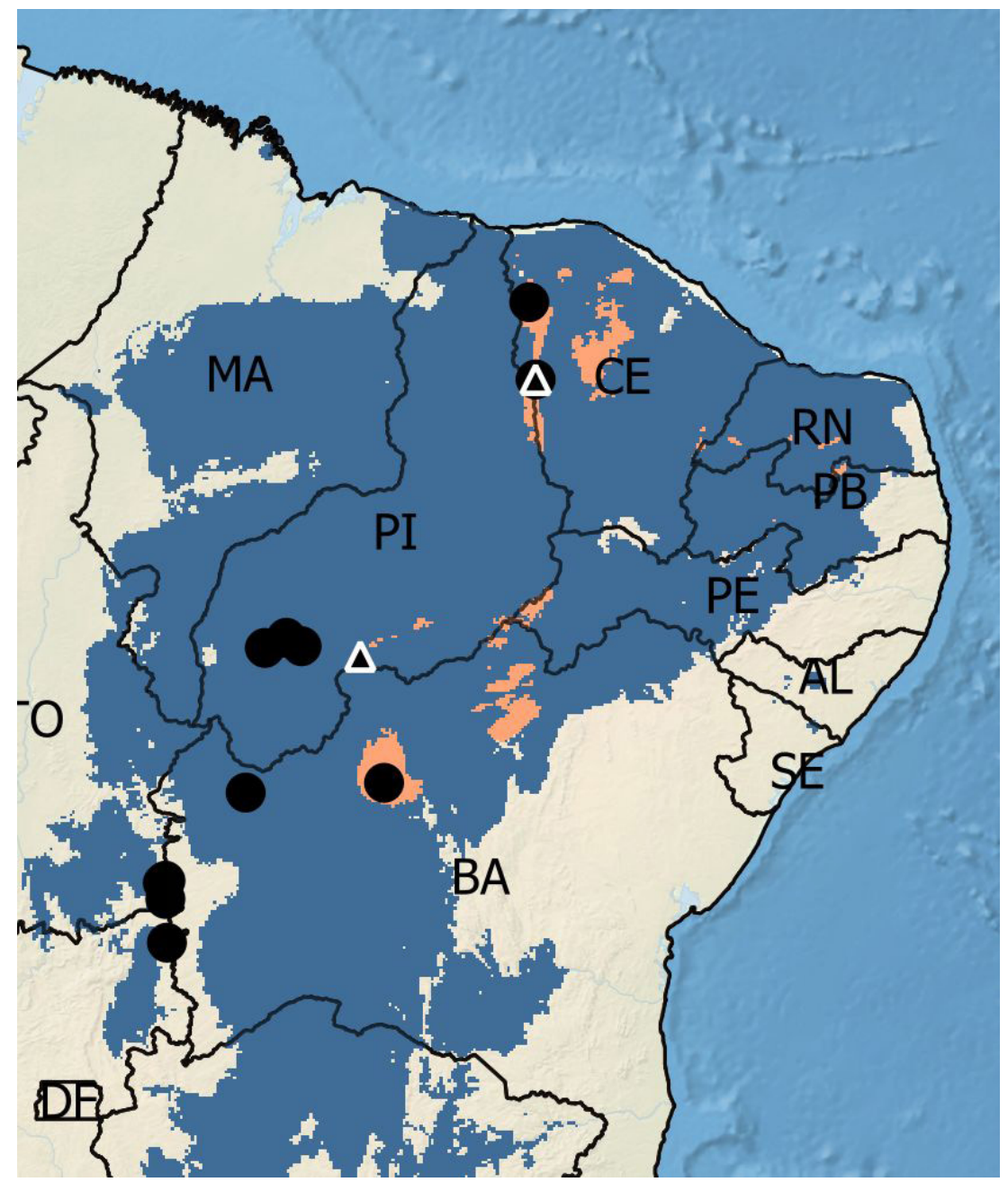

Figure 4 Geographic records and projection of distribution of Paratetrapedia nordestina (triangles and red cover) and Camargoia nordestina (circles, blue cover).

on the core area of the distribution of $C$. nordestina, on eastern Piauí and western Ceará states.

This complex system must be studied in more detail and may also involve other species with sting, like Osirini bees, other solitary bees and paper wasps, with almost identical size and color. The knowledge of this system is also important to support conservation strategies over core areas of the semideciduous forests, where these mimetic complexes persist under a fragile balance between mimic and model populations.

\section{Acknowledgments}

Brunno Rosa is thanked for taking part in the field work in Ceará and Arlete Soares (UFC) for her kind assistance and support during our stay in Ceará in 2014, and for making possible the collecting trip to the RPPN Serra das Almas. We also thank Airton Carvalho for the loan of the specimen from UFMG collection and Andre Martins for taking photographs of Paratetrapedia nordestina sp. nov. and Camargoia nordestina (DZUP). Partial financial support has been received by grants from CNPq to GARM (304053/2012-0 and 309641/2016-0).

\section{Conflicts of interest}

The authors declare no conflicts of interest.

\section{Author contribution statement}

AJCA planned the work, with input from GARM, and wrote the first draft of the manuscript. Both authors revised the final version. MCV collected and analyzed the distribution data.

\section{References}

Aguiar, A. J. C., 2009. Taxonomic revision of the bee genus Lophopedia Michener and Moure (Hymenoptera, Apidae, Tapinotaspidini). Zootaxa 2193, 1-52. https://doi.org/10.11646/zootaxa.2193.1.1.

Aguiar, A.J. C., 2018. New species of Nasutopedia from cloud forests of the Neotropical region (Hymenoptera: Apidae: Tapinotaspidini). J. Nat. Hist. 52, 2283-2300. https://doi.org/10.1080/00222933.2018.1527962.

Aguiar, A. J. C., Melo, G. A. R., 2007. Taxonomic revision, phylogenetic analysis, and biogeography of the bee genus Tropidopedia (Hymenoptera, Apidae, Tapinotaspidini). Zool. J. Linn. Soc. 151 (3), 511-554. http://dx.doi.org/10.1111/j.1096-3642.2007.00328.x. Aguiar, A. J. C., Melo, G. A. R., 2011. Revision and phylogeny of the bee genus Paratetrapedia Moure, with description of a new genus from the Andean Cordillera (Hymenoptera, Apidae, Tapinotaspidini). Zool. J. Linn. Soc. 162 (2), 351-442. http://dx.doi.org/10.1111/j.10963642.2010.00678.x.

Aguiar, A. P., Deans, A., Engel, M., Forshage, M., Huber, J., Jennings, J., Johnson, N. F., Lelej, A. S., Longino, J., Lohrmann, V., Mikó, I., Ohl, M., 
Rasmussen, C., Taeger, A., Yu, D. S., 2013. Order Hymenoptera. In: Zhang, Z.-Q. (Ed.) Animal biodiversity: an outline of higher-level classification and survey of taxonomic richness (Addenda 2013). Zootaxa 3703 (1), 51-62. http://dx.doi.org/10.11646/zootaxa.3703.1.12.

Albuquerque, P. M. C., Rêgo, M. M. C., 1989. Fenologia das abelhas visitantes de murici (Byrsonima crassifolia, Malpighiaceae). Bol. Mus. Para. Emilio Goeldi 5, 163-178.

Bates, H. W., 1862. Contributions to an insect fauna of the Amazon valley. Lepidoptera Heliconidae. Trans. Linn. Soc. Lond. 23 (3), 495-566. http://dx.doi.org/10.1111/j.1096-3642.1860.tb00146.x.

Brothers, D. J., 1976. Modifications of the metapostnotum and origin of the "propodeal triangle" in Hymenoptera Aculeata. Syst. Entomol. 1 (3), 177-182. http://dx.doi.org/10.1111/j.1365-3113.1976.tb00036.x.

Camargo, J. M. F., 1996. Meliponini neotropicais: o gênero Camargoia Moure, 1989 (Apinae, Apidae, Hymenoptera). Arq. Zool. 33 (2), 71-92. http://dx.doi.org/10.11606/issn.2176-7793.v33i2-3p71-92.

Dalapicolla, J., 2015. Tutorial de modelos de distribuição de espécies: guia prático usando o Maxent e o Arcgis 10. Laboratório de Mastozoologia e Biogeografia, Universidade Federal do Espírito Santo, Vitória. Available in: http://blog.ufes.br/lamab/tutoriais (accessed 09 October 2020).

Faria, L. R. R., Melo, G. A. R., 2012. Species of Euglossa of the analis group in the Atlantic forest (Hymenoptera, Apidae). Zoologia 29 (4), 349-374. http://dx.doi.org/10.1590/S1984-46702012000400008.

Fielding, A. H., Bell, J. F., 1997. A review of methods for the assessment of prediction errors in conservation presence/absence models. Environ. Conserv. 24(1), 38-49. http://dx.doi.org/10.1017/S0376892997000088.

Forbes, A., Bagley, R. K., Beer, M. A., Hippee, A. C., Widmayer, H. A., 2018. Quantifying the unquantifiable: why Hymenoptera, not Coleoptera, is the most speciose animal order. BMC Ecol. 18 (1), 1-11. http:// dx.doi.org/10.1186/s12898-018-0176-X.

Griswold, T., Gonzalez, V. H., 2015. Hidden species complexes within distinctive taxa: the case of Epanthidium bicoloratum (Smith) (Hymenoptera: Megachilidae). In: Aguiar, A.J.C., Gonçalves, R.B., Ramos, K.S. (Eds.), Ensaios sobre as abelhas da região Neotropical: homenagem aos 80 anos de Danuncia Urban. Editora UFPR, Curitiba, pp. 245-266.

Instituto Brasileiro de Geografia e Estatística - IBGE, 2004. Mapa de Vegetação do Brasil. IBGE, Rio de Janeiro.

Lessa, T., Santos, J. W., Correia, R. A., Ladle, R. J., Malhado, A. C. M., 2019. Known unknowns: filling the gaps in scientific knowledge production in the Caatinga. PLoS One 14 (7), e0219359. http:// dx.doi.org/10.1371/journal.pone.0219359.

Matricardi, E. A., Aguiar, A. S., Miguel, E., Ângelo, H., Gaspar, R., 2018. Modelagem do desmatamento na região do Matopiba. Nativa 6 (2), 198-206. http://dx.doi.org/10.31413/nativa.v6i2.5092.

Melo, G. A. R., 2015. New species of the stingless bee genus Schwarziana (Hymenoptera, Apidae). Rev. Bras. Entomol.59(4), 290-293. http:// dx.doi.org/10.1016/j.rbe.2015.08.001.

Melo, G. A. R., 2020. Stingless bees (Meliponini). In: Starr, C. (Ed.), Encyclopedia of Social Insects. Springer, Switzerland, pp. 1-18. https://doi.org/10.1007/978-3-319-90306-4_117-1.

Michener, C. D., 1944. Comparative external morphology, phylogeny, and a classification of the bees. Bull. Am. Mus. Nat. Hist. 82, 151-
326. Available in: http://hdl.handle.net/2246/1272 (accessed 09 October 2020).

Michener, C. D., 2007. The Bees of the World. 2nd ed. The Johns Hopkins University Press, Baltimore.

Moure, J. S., Urban, D., Melo, G. A. R., 2007. Catalogue of Bees (Hymenoptera, Apoidea) in the Neotropical Region. Sociedade Brasileira de Entomologia, Curitiba.

Pfennig, D. W., Harper Junior, G. R. J., Brumo, A. F., Harcombe, W. R., Pfennig, K. S., 2007. Population differences in predation on Batesian mimics in allopatry with their model: selection against mimics is strongest when they are common. Behav. Ecol. Sociobiol. 61 (4), 505-511. http://dx.doi.org/10.1007/s00265-006-0278-x.

Phillips, S. J., Anderson, R. P., Schapire, R. E., 2006. Maximum entropy modeling of species geographic distributions. Ecol. Modell. 190 (3-4), 231-259. http://dx.doi.org/10.1016/j.ecolmodel.2005.03.026.

Prudic, K. L., Oliver, J. C., 2008. Once Batesian mimic, not always a Batesian mimic: mimic reverts back to ancestral phenotype when the model is absent. Proc. Biol. Sci. 275 (1639), 1125-1132. http:// dx.doi.org/10.1098/rspb.2007.1766.

Prudic, K., Timmermann, B., Papaj, D., Ritland, D. B., Oliver, J. C., 2019. Mimicry in viceroy butterflies is dependent on abundance of the model queen butterfly. Commun. Biol. 2 (68), 1-9. http://dx.doi. org/10.1038/s42003-019-0303-z.

Queiroz, L. P., Cardoso, D., Fernandes, M. F., Moro, M. F., 2017. Diversity and evolution of flowering plants of the Caatinga domain. In: Silva, J.M.C., Leal, I.R., Tabarelli, M. (Eds.), Caatinga. Springer, Cham, pp. 23-63. http://dx.doi.org/10.1007/978-3-319-68339-3_2.

Rêgo, M. M. C., Albuquerque, P. M. C., 1989. Comportamento das abelhas visitantes de murici, Byrsonima crassifolia(L.) Kunth, Malpighiaceae. Bol. Mus. Para. Emílio Goeldi. Zoologia 5, 179-193.

Segurado, P., Araújo, M. B., Kunin, W. E., 2006. Consequences of spatial autocorrelation for niche-based models. J. Appl. Ecol. 43 (3), 433 444. http://dx.doi.org/10.1111/j.1365-2664.2006.01162.x.

Silveira, F. A., 1995. Phylogenetic relationships and classification of Exomalopsini with a new tribe Teratognathini (Hymenoptera: apoidea). Univ. Kans. Sci. Bull. 55 (12), 425-454. https://doi. org/10.5962/bhl.part.780.

Urban, D., 1967. As espécies do gênero Thygater Holmberg, 1884. Bol. Univ. Parana. 2 (12), 177-309.

Uvo, C. B., Berndtsson, R., 1996. Regionalization and spatial properties of Ceará State rainfall in Northeast Brazil. J. Geophys. Res. 101 (D2), 4221-4233. http://dx.doi.org/10.1029/95JD03235.

Wiley, E. O., Lieberman, B. S., 2011. Phylogenetics: Theory and Practice of Phylogenetic Systematics, 2nd ed. Wiley-Blackwell, Hoboken.

Winston, J., 1999. Describing Species: Practical Taxonomic Procedure for Biologists. Columbia University Press, New York. 